\begin{tabular}{|l|l|l||}
\hline \multicolumn{2}{|c|}{ PublisherInfo } \\
\hline \hline PublisherName & $:$ & BioMed Central \\
\hline \hline PublisherLocation & $:$ & London \\
\hline \hline PublisherImprintName & $:$ & BioMed Central \\
\hline \hline
\end{tabular}

\title{
Pollen coat protein gene families
}

\begin{tabular}{|l|l|l||}
\hline \multicolumn{2}{|c|}{ ArticleInfo } \\
\hline \hline ArticleID & $:$ & 4135 \\
\hline \hline ArticleDOI & $:$ & $10.1186 /$ gb-spotlight-20010703-01 \\
\hline \hline ArticleCitationID & $:$ & spotlight-20010703-01 \\
\hline \hline ArticleSequenceNumber & $:$ & 206 \\
\hline \hline ArticleCategory & $:$ & Research news \\
\hline \hline ArticleFirstPage & $:$ & 1 \\
\hline \hline ArticleLastPage & $:$ & 2 \\
\hline \hline & & RegistrationDate : 2001-07-03 \\
ArticleHistory & $:$ & OnlineDate \\
\hline \hline ArticleCopyright & $:$ & BioMed Central Ltd2001 \\
\hline \hline ArticleGrants & $:$ & \\
\hline \hline ArticleContext & $:$ & 130592211 \\
\hline \hline
\end{tabular}




\section{David Bruce}

Email: david.bruce@biomedcentral.com

Plant fertilization is a highly specific process involving the interaction of a number of pollen coat proteins with the surface of the stigma. In the 29 June Science, Jacob Mayfield and colleagues from the University of Chicago report that the genes that encode these pollen coat proteins in the brassica Arabadopsis thaliana are found in clusters within the genome (Science 2001, 292:2482-2485).

Mayfield et al. identified two distinct clusters of coat proteins: one cluster encoding six lipases and the second a group of six lipid-binding oleosin genes, including the pollination-initiation gene GRP17. Following the identification of these gene clusters they decided to explore how the clusters were distributed in other 'ecotypes' - Arabadopsis strains from disparate geographical locations. They found that although there was variation within the genes themselves, the clusters were conserved across the ecotypes, suggesting a strong evolutionary pressure to maintain the clusters.

In addition they compared the pollen coat proteins of Arabidopsis with those of another brassica, broccoli and discovered a large degree of diversity. This could imply that these genes are involved in speciation and species recognition.

These findings could have important ramifications. They may enable the manipulation of pollen to enable cross fertilization of species that have so far proved impossible; and it may also make possible alteration of the pollen coat of genetically modified crops so that they are unable to fertilize wild plants.

\section{References}

1. Mayfield JA, Fiebig A, Johnstone SE, Preuss D: Gene families from the Arabidopsis thaliana pollen coat proteome. Science 2001, 292:2482-2485., [http://www.sciencemag.org/]

2. University of Chicago, [http://www.uchicago.edu/]

This PDF file was created after publication. 